\title{
The Construction of English for Academic Purposes Curriculum System of Postgraduates
}

\author{
Zhou Xia ${ }^{1}$, Ding Jie $^{2,}$ a , Zhao Guotao ${ }^{1}$ \\ ${ }^{1}$ School of Foreign Languages of Hubei Engineering University, Xiaogan 432000, China \\ ${ }^{2}$ College of Technology of Hubei Engineering University, Xiaogan 432000, China \\ adj18822684@163.com
}

Keywords: EAP; postgraduates English; English curriculum; English for academic purpose; non-English major

\begin{abstract}
Conducting English for academic purposes (EAP) for non-English major postgraduates can effectively cultivate the academic communicative competence and multicultural adaptability of postgraduates in English. While, curriculum setting plays a very important role in teaching. The purpose of English curriculum for non-English majors is to enable postgraduates to grasp and use English to understand the latest scientific and technological developments in the world, to participate in inter-regional exchanges, to explore ideas and develop innovative abilities and to seize the right to speak in the international economic, political, academic. Through literature research and empirical research, this paper examines current research and practice status of non-English major English curriculum in China. Based on the analysis of the Chinese characteristics of EAP in Chinese postgraduates, the author proposes the concept of establishing EAP curriculum system for non-English majors with Chinese characteristics, helping non-English majors to cultivate their academic communication skills, integrating English into international academic circles and spreading Chinese tradition cultural.
\end{abstract}

\section{Introduction}

Nowadays, when the society enters into information and network age, the role and value of English as an international universal language are very prominent. With the improvement of our international status, science and technology and educational activities are increasingly internationalized. The current postgraduate English curriculum is obviously unable to meet the needs of national and social talents training in the context of internationalization. The postgraduate English curriculum system is facing the problem of reorientation. The goal of postgraduates teaching is to cultivate high-level and high-quality scientific research personnel who can independently engage in professional research, to write and publish academic papers in line with international standards, and to be able to communicate at international academic conferences[1]. These needs are manifested in the curriculum system as follows: the structure of the course is reasonable and the individualized elective courses can fully consider the difference of learners; the curriculum system is flexible and the courses are set up in accordance with the professional and academic communication skills[2]. The establishment of English for academic purpose has become the only way for the reform and development for postgraduate English teaching. The ultimate goal of postgraduate English teaching is to combine language learning with professional knowledge to develop postgraduate English application skills and to help them flexibly use linguistic tools to better carry out their research and engage in professional work to make them an international application of social necessity innovative talent[3]. English curriculum setting is the foundation of postgraduate English teaching. Through literature research and empirical investigation, this paper examines current research and practice status of non-English major English curriculum system in China, and proposes an English for academic purpose curriculum system for postgraduates that meets the developmental requirements of our country. 


\section{The Status of English for Academic Curriculum System in Postgraduates}

Although the common teaching aims and objectives are stipulated in the outline, the English curriculum system of each school is different. Taking class hours as an example, the intercollegiate differences in postgraduate English teaching are very large, ranging from 144 to 32 course hours. Instead of taking student characteristics or English teaching objectives into account, the school-time schedule of many schools is subject to the school's graduate education program[4]. They have implemented exemption except individual university, but the exemption standard setting are different. There are also schools who specially set up examination and grading admission exemption, exemption teaching according to the examination results. From the scale of the class, it is difficult for most schools to teach small classes in accordance with the characteristics of English courses. The number of students in each class is above 30, even up to 70. The English teaching mode which has been followed by the undergraduate course can not reflect the specific goals, group characteristics and social needs of postgraduate English learning[5]. Most colleges and universities have implemented graded teaching and elective courses, but there are also no elective courses in universities[4]. In fact, some elective courses offered in some colleges and universities are actually optional courses, which often occur to be canceled when it is unable to meet the requirements of the course. Most colleges and universities are using their own textbooks, teaching materials are different[5]. The application of modern education theory and technology is not enough, the construction of network teaching platform is in the exploratory stage, which fails to realize the rational allocation and sharing of teaching resources.

What's more, most of the present postgraduate English teaching focuses on general English teaching and lacks a perfect academic English course system. Therefore, under the new educational background, it is obviously impossible to meet the needs of the research talents in the contemporary society. It is imperative to negotiate the system of English for academic purpose curriculum for postgraduates.

\section{English for Academic Purpose Curriculum System for Postgraduates}

\section{First: Establishing a system of exemption and elective for postgraduate English course}

Due to the expansion of postgraduate enrollment scale, the freshmen of postgraduates have uneven ability in English application. Students with high English proficiency have met or even exceeded the requirements of postgraduate English teaching at undergraduate level[6]. Establishing a system of exemption from postgraduate English courses, that is to say, students who have reached a certain standard can be exempt from basic English courses for graduate students and go directly to the study of English for academic purpose. This not only avoids the waste of resources in repetition of basic courses, but also facilitates personalized learning and active learning better interface with undergraduate English teaching.

\section{Second:Establishing a diversified, hierarchical, academic English-oriented curriculum system}

In the teaching of postgraduate English, an academic English oriented curriculum system should be implemented. The curriculum system is divided into three modules: basic English module, English for academic purpose module and English for special purpose module, the implementation of these three modules are go forward one by one. Students who complete basic English module learning or obtain basic English exemption qualifications can enter English for academic purpose module. And when they passing the test of English for academic purpose, they can enter English for special purpose module. Progressive criteria are based on student performance and final exams for each semester. In the postgraduate English curriculum, the basic English module is first considered, because only when students have certain basis English can they combined English with majors and disciplines. With the deepening of global integration, the internationalization of students has become the new core of postgraduate teaching content[7]. How to improve students' international academic exchange level and train students' English application ability has also become the focus of research. After many years of study, most non-English majors have a high level of English, but some of them have a weak English proficiency. In order to ensure that these graduate students can 
complete English language courses better, it is necessary to establish basic English among postgraduates. The specific implementation plan is based on the English scores of annual national postgraduate entrance exam and the grades of postgraduate English entrance exam that school organized to determine the basic English-free graduate standards. Basic English courses are offered for students who do not qualify for exemption. The course is compulsory, the course types are divided into English audition, reading, writing and translation, the purpose is to develop students' basic skills of listening, speaking, reading and writing. Students who have obtained basic English exemption qualifications may directly enter the English for academic courses. English for academic purpose is a specialized discipline of English teaching. It focuses on specific disciplines (such as medicine, law, engineering and other disciplines) vocabulary grammar, genre and workplace English communication strategies and skills training. Colleges and universities may offer courses such as educational English, computer English and business English according to their schools and specialties. There are obvious differences between professional vocabulary and knowledge content in teaching content, such as mechanical and electronic writing experiment reports, legal cases, legal cases and business contracts.At the same time, emphasis is placed on English skills, such as technical report writing, conference presentation, and so on.. Teaching focuses on English skills in professional communication and writing, integrating skills training into professional knowledge courses. The students of the same profession make up a class and take a project driven teaching method. English for academic purpose is a form of language teaching driven by learning contents and forms. It is different from basic English in terms of professional needs rather than exam oriented needs. After the English for academic purpose module, postgraduates should be able to write essays in English and communicate with others in English. And if they have energy and interest in English for special purpose, they can participate in it willingly. Through this module, they can learn what they want to learn without limitation and examinations.

\section{Third: Adding scientific and technical English paper writing course}

Based on the professional needs of postgraduate students, English teaching and professional learning and research are combined to increase the basic methods of postgraduate student literature retrieval and the basic paradigm of scientific and technological essay writing, and to set up a certain period of science and technology essay writing courses. The goal of the teaching is to help students grasp the language features, text structure and writing requirements of English scholarly papers. And help to develop students 'ability to acquire academic information, make academic innovations, analyze and solve problems comprehensively, and improve students' ability to use English to publish academic essays and communicate in English. While, the postgraduate English course should also improve the students' ability to apply English in the academic field. Through interactive classroom activities, non-English majors will be trained to read scientific articles, discuss and read the dissertation skills. Academic thesis writing teaching includes corpus analysis, writing academic dissertations by chapters and writing complete academic dissertations[6]. This teaching arrangement aims to reinforce students' in-depth knowledge and understanding of the basic elements, textual structure and language characteristics of English academic dissertations. According to the text structure and language characteristics of the academic paper, the practical writing task is arranged, and the students will gradually write every chapter of the paper. In the process of writing, students can understand the ideas of the study more clearly, and finally master the writing methods and essentials of writing academic papers. Through classroom feedback and interactive discussion, the students 'interest in learning is stimulated, the students' initiative and creativity are fully displayed, the task of writing in the classroom is completed with high quality, and students are gradually established their self-confidence and enthusiasm in composing and publishing English dissertations. By arranging academic thesis writing tasks, we can improve students' ability to write English academic papers, so as to truly achieve the goal of improving postgraduate's academic English communication ability.

In addition, postgraduate English courses are guided by language output. During the course of classroom teaching, students have set up a variety of language output activities aimed at improving students' language application ability, such as group discussions, simulating international 
conference speeches and question answering sessions. The classroom learning and professional knowledge combined to enhance student learning initiative. Postgraduate English course exam emphasizes process assessment of student learning. The examination of students' verbal and written language tasks is an important part of the formative assessment assessment system. In the learning process, students participate in classroom teaching activities, after-school writing and other output links are students' usual grade considerations.

\section{Conclusion and Recommendation}

For both academic postgraduates and professional postgraduates, as English becomes a common language in academia, postgraduates' English academic communication skills are closely linked with their careers and academic qualifications. Regardless of any subject, the setting of the curriculum is of paramount importance. Therefore, the construction of the postgraduate English for academic purpose curriculum system with Chinese characteristics can improve the students' ability to construct English academic communication and cultural adaptation. However, the new model of academic English curriculum is a systematic project. It is necessary to fully integrate the characteristics of Chinese students and existing English teaching models in order to truly meet the needs of Chinese students and meet the needs of social development for scientific workers. In this article, the author puts forward the postgraduate English for academic purpose curriculum system combining with the characteristics of Chinese graduate students, hoping to provide reference for the graduate English curriculum.

\section{Acknowledgements}

This work was financially supported by General project of Hubei Social Science Fund (2016149) ,the Science and Technology Research Project of Education Department of Hubei Province (B2017 501).

\section{Reference}

[1] Cai Jigang. On the course setting and teaching goals of College English -- reference to the English Curriculum in Hongkong University[J]. Foreign Language Teaching and Research, 2011(4)

[2] Luo Na, Xiao Qiaoling. Exploration of Master 's EAP Acquisition Model[J]. The theory and practice of foreign language teaching, 2011, (3):81

[3] Yang Xiaoqiong. Discussion on the design of EAP course in Chinese Context[J]. Foreign languages,2014(4):148-151.

[4] Cai Jigang. English for Comprehensive purpose or English for academic purpose-a directional problem that must be thought clearly[J]. Journal of Northeast Normal University: Philosophy and Social Sciences Edition,2012(1):94 96.

[5] Geng Yanhong, Zhang Xiuqig. Strategy of Rebuilding Foreign Language Teaching System of Graduate Students under CDIO Theory [J]. The Research of Higher Education in Heilongjiang, 2012(3):81 83.

[6] Xia Jimei. On the Construction of English for Academic Purpose Curriculum in Universities and Colleges[J]. The theory and practice of foreign language teaching, 2014(1).

[7] Geng Yanhong. A tentative discussion on the transformation of postgraduate English teaching based on English for academic purpose[J]. The Research of Higher Education in Heilongjiang, 2014(2):146-148 